\title{
Asynchronous Collaborative and Interactive Learning Support System
}

\author{
A. Hadiana, L. Leiliawati, R. Rohmanto, M. Muslih, N. Natalia, and Y. Sudaryo
}

\begin{abstract}
We propose in this paper an educational distance learning support system to provide learning environment in higher education especially it is very important during Covid-19 pandemic. This system provides the collaboration functions among students, in order to make students more active and interactive in learning process based on web technology without any restriction of time and place, and also in order to decrease teachers' load. In this system students are endorsed to collaborate each other for constructing shared knowledge as much as possible according to their level of knowledge. Students can make discussions or ask some questions collaboratively to acquire more knowledge which cannot be gained through lessons. We describe the concept of this system including its architecture.
\end{abstract}

Index Terms - collaboration, learning system, distance learning, students, web technology.

\section{INTRODUCTION}

Recently, there are many internet technologies including web which can be used for implementing educational support system, so it becomes possible that learning activities can be performed in distance without any restriction of time and place [1]-[3], especially in emergency condition such as Covid-19 Pandemic e-Learning system plays as critical solution to support learning activities [4]. In general, the application of distance learning system is divided into two categories; the one is synchronous and the other is asynchronous [5], [6]. In this paper, we are focusing on asynchronous learning system and their collaboration functions.

In general, when a teacher has to give answer related to many questions from students who do not comprehend the contents of learning-materials, there is a tendency that the teacher's load becomes large, because the teacher directly has to answer the questions. On the other hand, collaboration activity plays important role in learning to increase the knowledge [6], and also could reduce the teachers load [8], [9]. So that in this system, we provide the collaboration tools to motivate students to be more active in learning process by teaching each other about some learning-materials related to their comprehension.

We propose three asynchronous collaboration tools (discussion, question/answer, and whiteboard) suited for

Submitted on February 28, 2021.

Published on March 22, 2021.

A. Hadiana, Research Center for Informatics - LIPI, Indonesia.

(e-mail: anahadiana.p2i.lipi@ ${ }^{@}$ gmail.com)

L. Leiliawati, STMIK-LIKMI, Bandung, Indonesia.

(e-mail: eldobe12020@gmail.com)

M. Muslih, STMIK-LIKMI, Bandung, Indonesia.

(e-mail: muhammadmuslih26@gmail.com) students' level of knowledge concerning to learning-material. In this system, if a student has a question or interesting theme for discussion, they can collaborate with each other to solve the problem according to their pace of learning [10]-[13]. Hence, the teacher's role is to monitor the learning process, and to give a proper advice indirectly to students in order to help the collaboration process [14]-[18].

Nowadays, there are many open-source web-based eLearning systems such as Moodle, ATutor, etc. [19], [20]. All of them have the similar function to support distance learning via internet. Moodle and ATutor are popular learning system that provide learning activities including collaboration with various learning-materials such as video, text, images, etc. So, students can enjoy the learning anytime and from anywhere. However, Moodle and ATutor allow student to make collaboration without restriction of their level of learning progress, so that our system proposes collaboration between student based on their level of learning progress to improve their knowledge.

This paper describes about the learning sequence of this system in section 2 , collaboration tools in section 3 , and the system structure in section 4. Finally, in section 5 as conclusion it describes the current problems of our system and its future works.

\section{LEARNING SEQUENCE}

In this system, users (students and teacher) access the remote learning resource asynchronously through a web browser. Students' progress their learning by reading the learning-materials step by step according to a semi-ordered learning sequence. On the other hand, teachers supervise students' learning progress, and according to the situation teachers give some hints or advices to students using a suitable tool. Students can follow learning-materials according to their paces, and if they have any questions, they can get a suitable answer from other students, or start a discussion with other students. In principle, this system lets students collaboratively perform their learning together to increase their knowledge a much as possible.

In this system, students start and finish the learning process as shown in Fig. 1. Firstly, students have to registered in order to participate in this system. Only the registered students can login to the system. After login, the system will load learning-

R. Rohmanto, STMIK-LIKMI, Bandung, Indonesia

(e-mail: rickyrohmanto@ gmail.com.

N. Natalia, Politeknik Sukabumi, Indonesia.

(e-mail: nilanatalia ${ }^{\circledR}$ polteksmi.ac.id)

Y. Sudaryo, STIE INABA, Bandung, Indonesia.

(e-mail: y.sudaryo2@gmail.com). 
materials related to the students' status or progress. During the learning, student not only read or explore the learningmaterials, but also can collaborate with each other asynchronously to get more knowledge. Collaboration will give great influence on the final result of learning. The system will ask students to do tests at the end of every level of materials in order to recognize the degree of comprehension. If students failed in the test, they are forced to learn again the current or previous learning-materials until their comprehension become enough to learn the next material. When the students pass the test and want to continue their learning, this system will guide them according to the semiordered learning sequence, so that the students can follow the learning-materials according to their pace and their interest to the learning-materials. Students can stop the learning and logout from system any time.

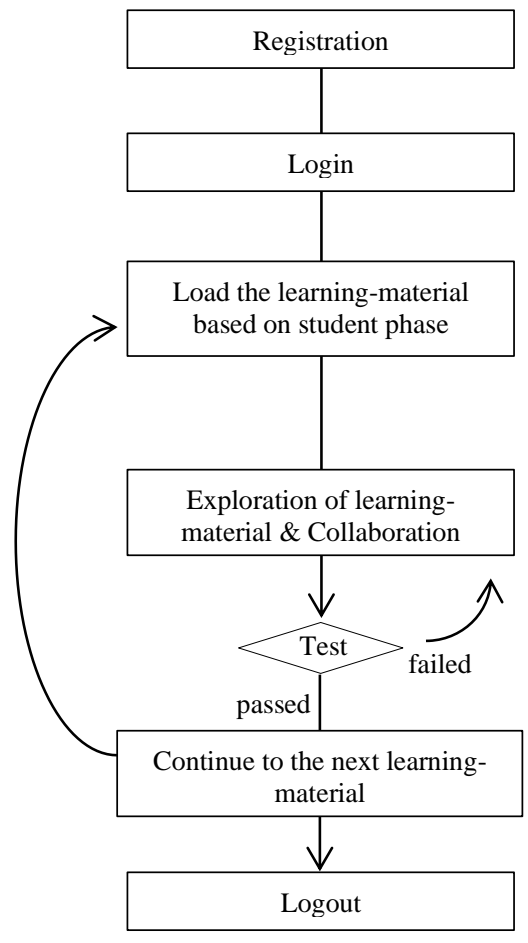

Fig. 1. Learning Process.

\section{COLLABORATION LEARNING}

During the learning process, the students not only read the learning-materials, but also are required to participate in many collaboration groups talking about some problems, because the collaboration plays critical role on asynchronous learning system. Collaboration gives many chances to find the problems' solution and makes it impossible for students to acquire more knowledge that is not contained in the learning-materials. Collaboration also would give students some motivation of learning through knowing other students' activities. Hence, collaboration not only gives students opportunities for more active communication with others, but also increases students' knowledge.

\section{A. Discussion}

The discussion may occur when two or more students have the same interesting learning theme related to the learningmaterial, but in this system only the students who have enough knowledge are allowed to participate in the particular discussion. The possible student's members of a discussion group are students who have read the related learningmaterials and understood it. It means the discussion can be performed within the groups whose members have the same or greater understanding level than learning-material's level. The teacher also may participate in discussion to help students attain the intended knowledge. Collaboration by active discussion can be considered as a way for deepening further knowledge.

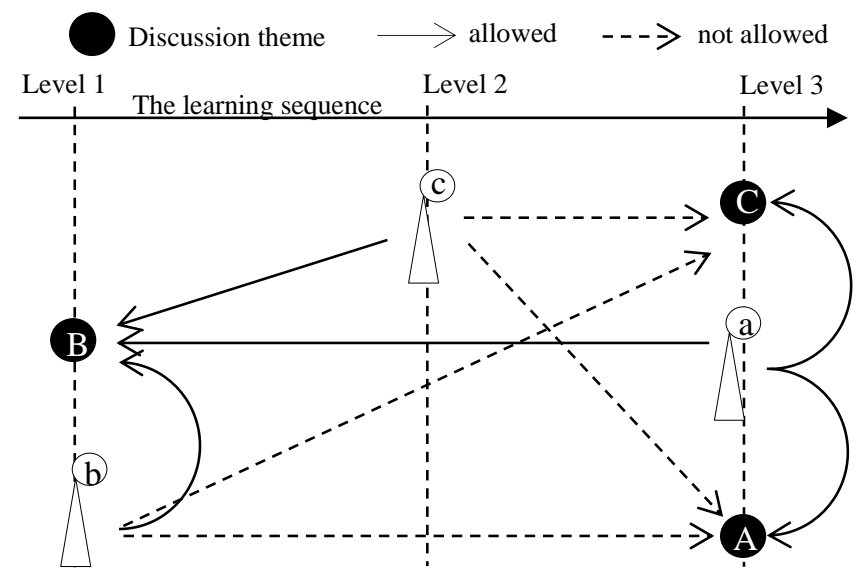

Fig. 2. Discussion Model

Each learning-materials may be divided into some discussion groups. For example, in Fig. 2 the student (a) who has reached level 3 is not only able to participate in the discussion of $\mathrm{C}$ and $\mathrm{A}$, but also to participate in the discussion favorably by uniting with each students' pace, the students (b) at level 1 and the student (c) at level 2 are not permitted to participate in discussion of A or C. Since the student (b) and (c) have not yet master the learning-materials at level 3, the system decides that their knowledge is not enough for joining the discussion.

\section{B. $Q \& A$}

Students sometimes have to face some problems related to learning-materials, so they need to ask a question. In this system students are not allowed to ask a question directly to teachers, and they are required to make collaboration with other students who have the knowledge to answer the question. Through Q\&A, this system will assist students to find qualified students who may know the answer, and also will assist students who act as respondents to answer the questions from the list of unanswered questions.

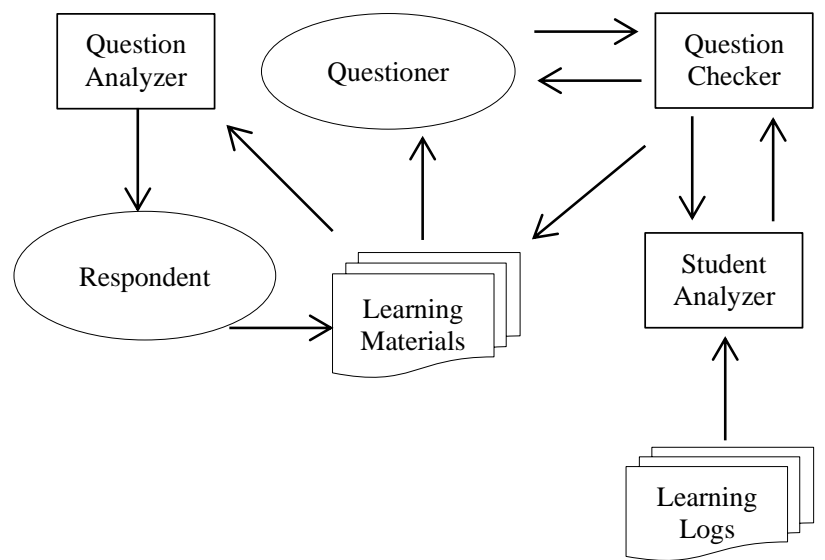

Fig. 3. Q\&A Model. 
We propose the following Q\&A as shown in Fig. 3, in order to realize the above requirement. The following is a typical Q\&A scenario.

1) During learning, students probably want to ask a question related to the content of the learning-materials. The question checker will guide the student to find the similar questions stored in the system using the keywords and the position of material. There are three possibilities in the process,

a) If the intended question exists and its answer is available, the student can find the answer directly.

b) If the intended question exists, but its answer is no available, then the students will be added as the questioner of this question.

c) If the intended question does not exist, then the student can create a new question. When a new question is generated, the student analyze will check all students based on the student model in order to find the qualified respondent for this new question.

2) The students who act as respondents will be given a list of questions, and then the question analyzer will assist them to answer the question one by one.

3) The Question analyzer will process and a arrange the number of questions using the priority. In this case, we use the priority such as the number of questioners for each question and waiting time of question.

4) Finally, the Q\&A will send the appropriated answer to all questioners.

The collaboration using Q\&A provides many opportunities to find the right solution of problems, and make students acquire more knowledge than just reading the learningmaterial. Collaboration also gives students some motivation of learning through knowing other students' activities and rechecks each other. Therefore, the collaboration not only makes students give many opportunities to be more interactive at communication with others in order to increase and improve the students' knowledge, and also ensures their comprehension.

\section{Whiteboard}

One of the most important collaboration methods in the learning process is presentation. Many learning materials can be used for presentation, such as journal, research report, et al. After learning the learning-materials, the students can make a presentation based on their views on these learningmaterials. During the learning of presentation, there would have a discussion organized by the teacher, in order to change the opinions, correct understanding and extend the relative knowledge by each other about a theme. The discussion on the same theme can be continued at different time asynchronously.

\section{SYSTEM STRUCTURE}

We use the web platform for implementing our asynchronous learning system as shown in Fig. 4. The configuration of software components for supporting the system are shown in Table I.
TABLE I: SOFTWARE CONFIGURATION

\begin{tabular}{ccccc}
\hline \hline OS & Programming & Database & $\begin{array}{c}\text { Web } \\
\text { Server }\end{array}$ & Others \\
\hline Linux & Java, Servlet, JSP & MySQL & $\begin{array}{c}\text { Apache, } \\
\text { Tomcat }\end{array}$ & $\begin{array}{c}\text { XML, } \\
\text { HTML }\end{array}$ \\
\hline \hline
\end{tabular}

The three tiers client-server architecture is adopted as the basic system design in the developing this learning system. Sot that, many students/teachers can access into the server together and use the system through their browsers in order to participate in learning and view learning-materials.

We developed the system using open source software, and Java is selected in our reseach as programming language in order that the system can be executed in various platform of operating system.

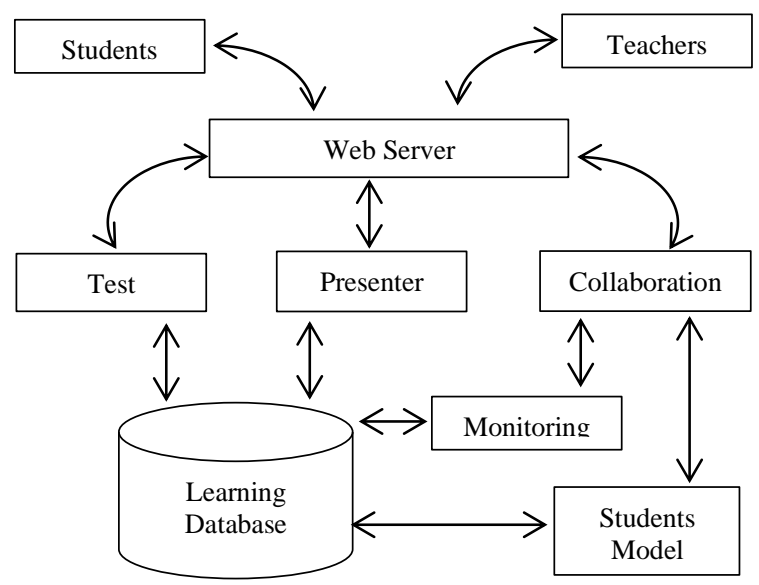

Fig. 4. Block Diagram of System.

As shown in Fig. 4 this system mainly consists of five modules of learning as follow.

\section{A. Presentation}

It is the most fundamental module that arranges and shows the learning-materials prepared by this system to students according to their level of learning. We use web browser as user interface for students and teacher.

\section{B. Test}

The learning-materials consist of some modules that include test for checking the degree of students' comprehension. The result of tests will be stored in a database and will be used again as learning data of test for the analyzing learning performance of students. The result of tests at each material will determine how learning to be continued. If a student fails in the test, the system will force the student to learn again the current material, but if a student passes the test, the student can proceed to the next level of learning.

\section{Student Model}

Basically, we use an overlay student model that decides the knowledge level of students to participate in collaboration, so that students can join the collaboration according to their pace of learning.

\section{Collaboration}

A collaboration function is used in order to acquire more satisfactory knowledge in addition to the knowledge acquired by reading the learning-materials. The main collaboration 
tools provided by the system are discussion, Q\&A, and whiteboard tools. Collaboration activity would give a big affection on result of learning, so the students who participate in it would acquire more knowledge through collaboration among them.

\section{E. Monitoring}

All students will be analyzed using a learning history data from database. The teachers are allowed to supervise the learning performance of all students and their collaboration condition. If it is necessary, the teachers also can give advices using suitable function.

\section{CONCLUSION}

This paper proposes the asynchronous learning support system for high education based on web platform. There are three main collaboration tools prepared by this system: discussion, Q\&A, and online Whiteboard. In this system the teachers do not participate in collaboration directly, but the teachers mainly supervise the situation of collaboration, and if necessary, the teachers can give some hints for directing learning process. Students can construct their knowledge not only by reading the teaching materials but also by collaborating each other, so that the final outcome of learning would be better.

We have developed the system, but we still have many problems to be solved, especially in Q\&A to make it more satisfactory tool for supporting collaboration.

In the future, we have to try to use this learning system in many cases as experiments in order to evaluate its performance. We also consider revising the appearance of user interface using Kansei engineering in order to redesign it based on students' emotional preferences.

\section{ACKNOWLEDGMENT}

The authors would like to thank to the students of post graduate Information System - STMIK-LIKMI Bandung for their active discussion, collaboration, and cooperation during this research. The authors also would like to thank to lectures of Politeknik Sukabumi and STIE Inaba for their cooperation and discussion. This research was also supported by the grant from Research Center for Informatics (P2I) - Indonesian Institute of Sciences (LIPI).

\section{REFERENCES}

[1] P. Aappvoo, "The Impact of a Technology-based approach for The Learning of Mathematics at Secondary School Level," Journal of eLearning and Knowledge Socety, Vol. 16 No. 4, pp. 76-85, December 2020.

[2] L. K. Wah, T. C. Keong, D. Lajium, and N. S. Ing, "Understanding the Blended Learning Experiences of English Language Teachers in a Distance TEST Degree Programme in Malaysia", Jurnal Teknologi, Vol.65 No.2, November 2013.

[3] A. Barate, L. A. Ludovico, "An Open and Multi-Layer Web Platform for Higher Music Education", Journal of E-Learning and Knowledge Society, Vol. 16 No. 4, pp. 29-37, December 2020.

[4] G. R. El Said, "How Did the COVID-19 Pandemic Affect Higher Education Learning Experience? An Empirical Investigation of Learner's Academic Performance at a University in a Developing Country", Advances in Human-Computer Interaction, Vol. 2021.
[5] K. C. Loudon, P. L. Jane, Management Information Systems; managing digital firm $15^{\text {th }}$ edition, New Jersey: Prentice Hall, 2012.

[6] U. Haruki., "Internet based Distance Learning for Lifelong Engineering Education - a Personal View and Issues", Information and System in Education, Vol.1, 2002.

[7] Y. Matsusita, Collaboration and Communication, Tokyo: Kyoritsu Publisher, 1995.

[8] P. Aappvoo, "The Impact of a Technology-based approach for The Learning of Mathematics at Secondary School Level," Journal of Education and E-Learning Research, Vol. 16 No. 4, pp. 76-85, December 2020.

[9] I. Bondar, T. Gumenyuk, etc, "Distance E-Learning in the System of Professional Development of Corporation Managers: Challenges of COVID-19”, Journal of Education and e-Learning Research, Vol.7 No.4, December 2020.

[10] F. Obayashi et al., "Construction and Evaluation of CAI System based on Learning by Teaching to Virtual Student", Information Processing Seminar Journal, Vol.41 No.12, 2000.

[11] A. Hadiana, K. Kaijiri, "The Construction of Asynchronous Q\&A Support System based on Collaboration", Information Technology Letters Forum on Information Technology, 2002.

[12] M. Tamaki et. al. "Multimedia Assisted Education System with Individual Student Advance", Information Processing Seminar Journal, Vol.41 No.8, 2000

[13] F. Redzuan, A. M. Lokman, Z. A. Othman, S. Abdulla, "Kansei Design Model for E-Learning: a preliminari finding, Proceeding of the $10^{\text {th }}$ European Conference on e-Learning (ECEL), 2011

[14] A. Hadiana, Analysis learners' Preferences in E-Learning System Using Kansei Approach, Book of trends in E-Learning, London: IntechOpen, 2018.

[15] V. O. Ochieng, R. M. Gyasi, "Open Educational Resources and Social Justice: Potentials and Implications for Research Productivity in Higher Educational Institutions", E-Learning and Digital Media, Vol.18 No.2, January 2021.

[16] P. Aappvoo, "The Impact of a Technology-based approach for The Learning of Mathematics at Secondary School Level," Journal of Education and E-Learning Research, Vol. 16 No. 4, pp. 76-85, December 2020

[17] A. Devisakti, T. Ramayah, "E-Learning Usage Outcomes among University Learners: A Pilot Study", Journal of Education and $e$ Learning Research, Vol.6 No.3, September 2019.

[18] R. D. H. Tobing, "Designing E-Learning System for Assisting Teachers Professionalism Improvement in Indonesia Rural Areas", Jurnal Teknologi Vol.78 No.6-3, August 2016.

[19] Moodle Learning Management System. Retrieved Januari 2021 from http://www.moodle.org.

[20] ATutor Learning Management System. Retrieved Januari 2021 from http://www.atutor.ca.

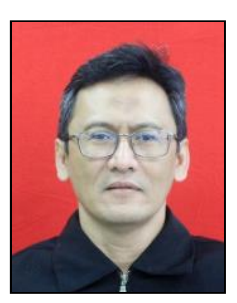

A. Hadiana was born in 1968. His majority research is Kansei engineering, software engineering, human computer interface, data mining, distance learning, and enterprise architecture.

He worked as researcher at National Institute for Informatics (NII) - Japan for one year in 2006. He is working as researcher at Research Center for Informatics - LIPI - Indonesia, and also is working as lecturer at the post graduate program STMIK LIKMI Bandung - Indonesia. He graduated B. Eng, M. Eng from Fukui University - Japan in 1993, 1995 respectively, and graduated Dr. Eng from Shinsyu University - Japan in 2004.

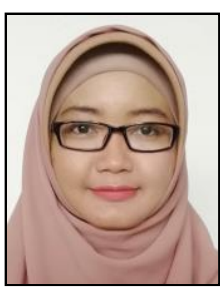

L. Leiliawati was born in 1976 . Her majority research is informatic management, business analysis, information business, and information system.

She graduated from Institut Teknologi Pertanian (IPB) Bogor in 1995 with Bachelor degree. She is working at government bureau. She is now studying at post graduate program of Information System - STMIK - LIKMI Bandung. 


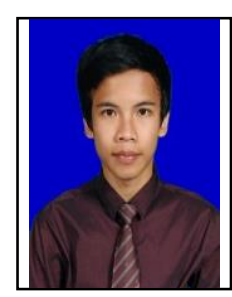

M. Muslih was born in 1991. His majority research is informatic management, business analysis, information business, and information system.

He graduated bachelor from Politeknik Piksi Ganesha Bandung in 2014. He is working at private company. He is now studying at post graduate program of Information System STMIK - LIKMI Bandung.

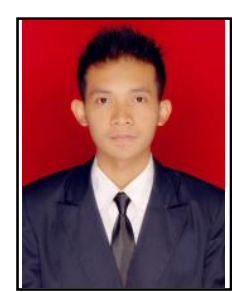

R. Rohmanto was born 1993. He is working at Ma'som University. His majority research are information system, system analysis and design, and informatic management.

He graduated bachelor from STMIK AMIK Bandung in 2015. He is now studying at post graduate program of Information System STMIK - LIKMI Bandung.

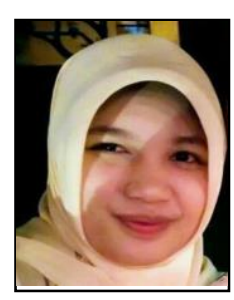

N. Natalia was born in 1987. She graduated from Post Graduate Program of STMIKLIKMI Bandung in 2017.

Her research concentration is information system, Kansei engineering and distance learning.

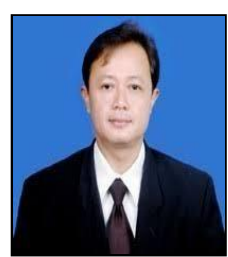

Y. Sudaryo was born in 1969. He graduated from Post Graduate Program of Information System STMIK-LIKMI Bandung in 2019.

$\mathrm{He}$ is working mainly as lecturer at STIE INABA Bandung, and several universities in Bandung.

His research concentration are information system, management, and research marketing. 